Check for updates

Cite this: RSC Adv., 2017, 7, 18578

\title{
Poly- $\gamma$-glutamic acid coupled Pseudomonas putida cells surface-displaying metallothioneins: composited copper(II) biosorption and inducible flocculation in aqueous solution $\dagger$
}

\author{
Penggao $\mathrm{Hu}^{a}{ }^{a}$ Zhongna Zhang, ${ }^{a}$ Fei Shen, ${ }^{a}$ Xun $\mathrm{Yu}^{a}$ Mingshun $\mathrm{Li}^{\mathrm{a}}{ }^{\mathrm{a}} \mathrm{Hong} \mathrm{Ni}$ \\ and $\mathrm{Lin} \mathrm{Li}(\mathbb{D}$ *a
}

Poly- $\gamma$-glutamic acid $(\boldsymbol{\gamma}$-PGA) is a biodegradable macromolecular polymer that is capable of adsorbing heavy metal ions through its side chains. In this study, a new biocomposite biosorbent that incorporates $\mathrm{Cu}^{2+}$ adsorption and recovery from aqueous solutions was developed through immobilization of a glutamine-binding protein GlnBP and cyanobacterial metallothionein SmtA onto the surface of Pseudomonas putida cells using an InaQ-N protein anchor, followed by coupling the cells with side chain-activated $\gamma$-PGA. The surface localization of the fusion protein $(\operatorname{InaQ})_{2}-\mathrm{G} \ln B P-(\mathrm{Smt} A)_{2}$ was confirmed by SDS-PAGE/Western blot, immunofluorescence microscopy and fluorescence-activated cell sorting assays. The engineered biocomposite MB546-PGA was capable of $\mathrm{Cu}^{2+}$ adsorption across a $\mathrm{pH}$ range of 3.5-5.5 and a relatively broad temperature range of $20-60{ }^{\circ} \mathrm{C}$, with a maximum adsorption capacity for $\mathrm{Cu}^{2+}$ of $145.99 \mathrm{mg} \mathrm{g}^{-1}$. The pseudo-second-order equation was applicable to the sorption data. Moreover, MB546-PGA exhibited an inducible flocculation capability following $\mathrm{Cu}^{2+}$ adsorption. The infrared spectroscopy data showed that the hydroxyl and amino groups of MB546-PGA were involved in $\mathrm{Cu}^{2+}$ adsorption, and $\gamma$-PGA likely bound to the cells through its carbonyl and amino groups. Given the features of the high capacity of $\mathrm{Cu}^{2+}$ adsorption and the easily inducible flocculation, the developed biosorbent shows potential for use in the remediation and purification of polluted or waste waters.

Received 7th February 2017 Accepted 15th March 2017

DOI: 10.1039/c7ra01546a

rsc.li/rsc-advances

\section{Introduction}

Metal pollution caused by various heavy metals from industrial processes has been a serious worldwide environmental threat. Copper is a commonly used heavy metal that is normally found in wastewater and effluents from electroplating, mining and various electronic industries. Because of the wide use, severe toxicity and non-degradability, copper ions ultimately accumulate in humans through the food chain, which poses a severe risk of health related problems to humans. ${ }^{1,2}$ Remediation of Cu-like heavy metal pollution often involves chemical, physical, and biological approaches. ${ }^{3,4}$ In the past few decades, biological remediation based on cell membrane-grafted metal-reacting chemical groups, which leads to the biosorption of metal ions onto the surface of intact cells or biocomposites, has attracted increasing interest because of its cost-effectiveness, high

${ }^{a}$ State Key Laboratory of Agricultural Microbiology, College of Life Science and Technology, Huazhong Agricultural University, Wuhan 430070, China. E-mail: lilin@mail.hzau.edu.cn; Fax: +86-27-8728-0670; Tel: +86-27-8728-6952

${ }^{b}$ College of Life Sciences, Hubei University, Wuhan 430062, China

$\uparrow$ Electronic supplementary information (ESI) available. See DOI: $10.1039 / \mathrm{c} 7 \mathrm{ra01546a}$ removal efficiency, and requirements for only moderate reaction conditions. ${ }^{5}$ Unfortunately, the conventional biosorption processes normally encounter difficulty in the separation of the biomasses from the effluents and in the desorption of the metals from the biosorbents. Therefore, it is still necessary to develop an innovative approach to solve these technical drawbacks.

Developments in biomass immobilization systems, particularly those using immobilized bacteria or fungi, provide a promising solution to these problems. Several previous investigations have attempted to immobilize biomasses on natural polymers, such as Ca-alginate gels, ${ }^{6}$ chitosan, ${ }^{7}$ activated carbon, ${ }^{8}$ polymer fibers, ${ }^{9}$ and volcanic minerals, ${ }^{10}$ to increase the mechanical strength and resistance to chemical constituents, and to facilitate the separation of the biosorbents from the effluents. The soluble biopolymer poly- $\gamma$-glutamic acid $(\gamma$-PGA) is formed by glutamate polymerization, which is primarily produced via bacterial fermentation. ${ }^{11} \gamma$-PGA produced by different bacterial species has different molecular configurations and molecular masses and consists of either $\mathrm{L}^{-}$or D-glutamic acid or a mixture of both enantiomers. ${ }^{12} \gamma$-PGA has been recognized as a new biomaterial with many biotechnologically 
extraordinary properties, as it is biodegradable, edible, nontoxic, and non-immunogenic to humans. ${ }^{13,14}$ Moreover, the enrichment of carboxyl groups in its side chains and the flocculation capacity in aquatic systems have special appeal for the development of a biocomposite adsorbent that could be used for the remediation of heavy metal pollution. ${ }^{15,16}$

Glutamine-binding protein (GlnBP) is a periplasmic protein that is responsible for glutamine transport. In Escherichia coli, GlnBP consists of 226 amino acids (aa) that form two globular domains connected by two flexible hinges. Previous studies have shown that the glutamine ligand between the two globular domains is bound by hydrogen bonds and ionic interactions. The $\alpha$-amino group of the glutamine ligand strongly interacts with Gly68, Thr70, and Asp157 of GlnBP via hydrogen bonds formed by the $\mathrm{NH}_{3}{ }^{+}$group of the glutamine ligand, the carbonyl group of Gly68, the carbonyl group of Thr70, and the side chain of Asp157. The $\alpha$-carboxyl group of the glutamine ligand interacts with Thr70, Arg75, and Gly119 of GlnBP via hydrogen bonds formed between the backbone $\mathrm{N}$ atoms of Thr70 and Gly119 and the ligand, as well as a salt bridge formed by the electron on the side chain of Arg75 and the $\mathrm{COO}^{-}$of the glutamine ligand. As expected, the glutamine ligand also binds to the cavity formed by Asp10, Gly68, Thr70, and Ala67 of GlnBP via hydrogen bonds and ionic interactions. ${ }^{17}$ In addition, GlnBP is thermostable, and glutamine can bind to GlnBP over a relatively broad range of $\mathrm{pH}$ values, temperatures, and ionic strengths. ${ }^{18}$

The display of a metal-binding protein (MBP) on the bacterial cell surface using cell surface display technology is an admirable strategy for removing heavy metals; it enhances the reaction rate, eliminates the mass transfer limitation, and minimizes the toxicity of heavy metals to living cells. ${ }^{19}$ The metallothioneins (MTs) are a family of cysteine-rich metalbinding proteins that are capable of taking up heavy metals from the environment. Microbial MTs mainly consist of the BmtA family of proteins and the Cu-binding protein MymT. Moreover, a cadmium-binding protein of the BmtA family, namely, SmtA from the cyanobacterium Synechococcus PCC7942, has the well-characterized ability to take up not only $\mathrm{Cd}^{2+}$ but also other metal ions, including $\mathrm{Zn}^{2+}, \mathrm{Cu}^{2+}, \mathrm{Hg}^{2+}$, etc. $^{20,21}$ At a low $\mathrm{pH}$ (as low as pH 2.35 for half dissociation), the adsorbed metal ions can be desorbed from SmtA. ${ }^{21}$ Thus, by displaying SmtA on the bacterial cell surface and by assigning different $\mathrm{pH}$ conditions, it is possible to govern the adsorption/ desorption cycles of metal ions and to remove and recover metal ions from polluted aquatic systems.

In the present study, we constructed a composite bioadsorbent with the polymer $\gamma$-PGA and the recombinant $P$. putida cells with SmtA surface-display to investigate the $\mathrm{Cu}^{2+}$ adsorption, the induced flocculation, and the desorption/ recovery of $\mathrm{Cu}^{2+}$ of this material. Firstly, P. putida AB92019 was engineered to display the fusion protein (InaQ-N) $)_{2}-\mathrm{GlnBP}-$ $(\mathrm{SmtA})_{2}$, which consisted of two tandemly repeated anchor InaQ-N proteins, ${ }^{22} \mathrm{GlnBP}$, and two repeats of SmtA. When exogenous $\gamma$-PGA was added, it bound to the GlnBP subunit of the fusion protein to form a triple composite biomaterial "Cell$\gamma$-PGA-Cell surface SmtA" (MB546-PGA). Subsequently, the optimal adsorption conditions, the adsorption kinetics, and the maximum adsorption capacity of $\mathrm{Cu}^{2+}$ of this biomaterial were determined. The interactions between $\gamma$-PGA and $P$. putida cells, as well as the biosorbent system and $\mathrm{Cu}^{2+}$, were examined using scanning electron microscopy (SEM) and Fourier transform infrared (FTIR) spectroscopy, respectively. Finally, experiments were conducted to investigate the flocculation activity upon the induction of certain coagulants and the adsorption/desorption activities of the biomaterial towards $\mathrm{Cu}^{2+}$.

\section{Results and discussions}

\section{Construction of recombinant $P$. putida MB546 and surface} localization analysis of the fusion protein (InaQ-N) $)_{2}-\mathrm{GlnBP}-$ $(\operatorname{SmtA})_{2}$

As shown in Fig. 1A, the recombinant pMB545 was constructed to express the fusion gene $(\text { ina } Q-N)_{2}-g \ln B P-(s m t A)_{2}$ that is driven by an $E$. coli-Pseudomonas dual-active constitutive promoter $P_{\text {opr. }}{ }^{23}$ Two copies of the $s m t A$ gene were used to construct pMB545 to increase the adsorption capacity of SmtA for metal ions. Theoretically, the fusion protein (InaQ-N) $)_{2}-\mathrm{GlnBP}-$ $(\mathrm{SmtA})_{2}$ has a molecular mass (Mr) of approximately $81 \mathrm{kDa}$. As shown in Fig. 1B, a band corresponding to a protein with a predicted $\mathrm{Mr}$ that was apparently equal to the $\mathrm{Mr}$ of (InaQ-N $)_{2}-$ GlnBP-(SmtA $)_{2}$ was clearly present in the MB546 profile (lane 1, indicated by an arrow), but was not found in the profile of the parent strain AB92019, verifying the accurate expression of this fusion protein in the host cells. This result was further confirmed by Western blot analysis, in which the profile of the expressed proteins from the whole cell fraction of MB546 cells (Fig. 1C, lane WC) revealed clear bands (Fig. 1C, lane WC), whereas no bands were observed in the control AB92019 cells (Fig. 1C, lane CK).

The Western blot profile of the outer membrane-complex fraction (OM) showed the presence of a protein band (Fig. 1C, lane OM) corresponding to the bands present in the WC fraction (Fig. 1C, lane WC) and the cytoplasmic fraction (CP) (Fig. 1C, lane CP), thereby confirming the surface localization of this fusion protein in principle. Immunofluorescence micrographs (Fig. 1D) and FACS analysis (Fig. 1E) also showed clear signs of the surface occurrence of (InaQ-N) $)_{2}-\mathrm{GlnBP}-(\mathrm{SmtA})_{2}$ on $P$. putida MB546 cells. In contrast, the control P. putida AB92019 cells were unable to react with externally added Cy5-labeled antiserum. Therefore, these assays confirmed the surface localization of (InaQ-N $)_{2}-\mathrm{GlnBP}-(\mathrm{SmtA})_{2}$ on P. putida MB546 cells.

\section{Preparation of the MB546-PGA biocomposite}

We developed a biocomposite adsorbent that consisted of the engineered P. putida MB546 cells and $\gamma$-PGA, which is presumed to confer a joint adsorption capacity for metal ions. $\gamma$-PGA was designed to bind to the surface of recombinant bacterial cells through two types of linkages: (i) covalent binding through the formation of amide bonds between the activated side chain carboxyl groups of $\gamma$-PGA and the amino groups of aa residues on the MB546 cell surface, such as those from lysine of GlnBP. 

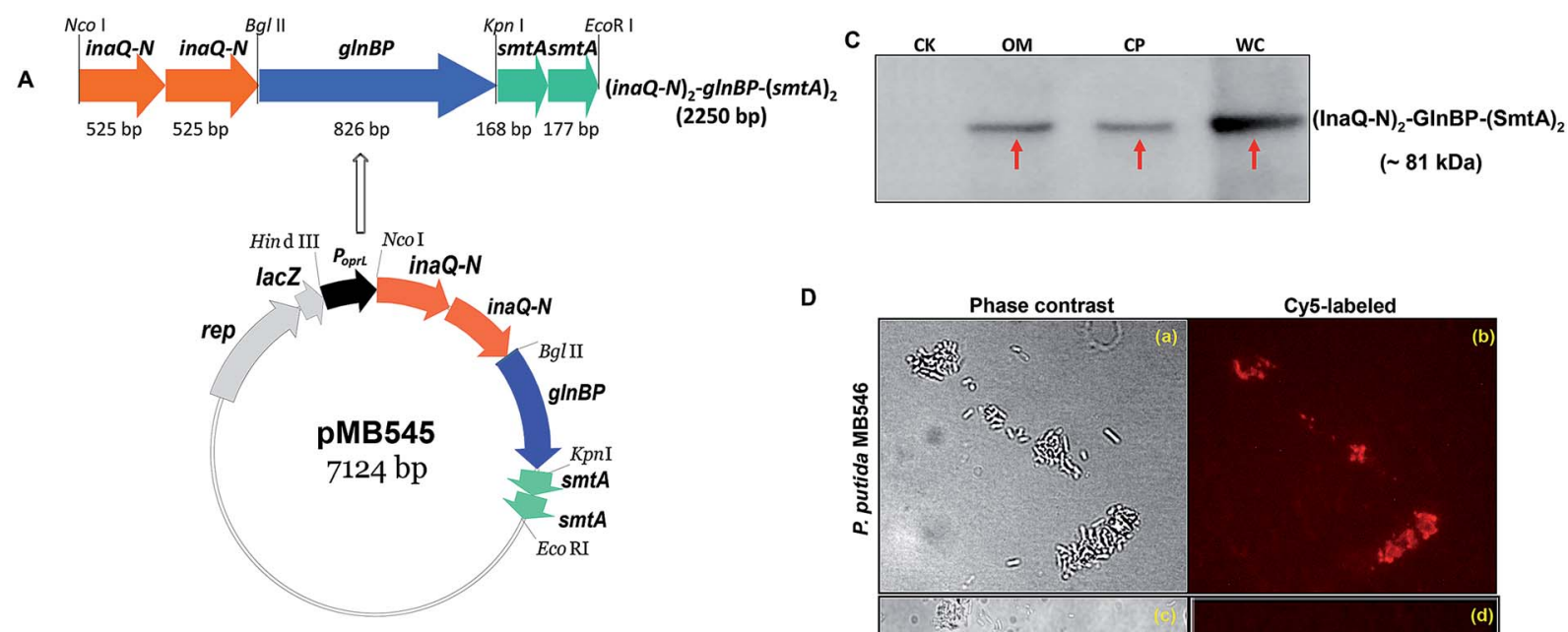

D
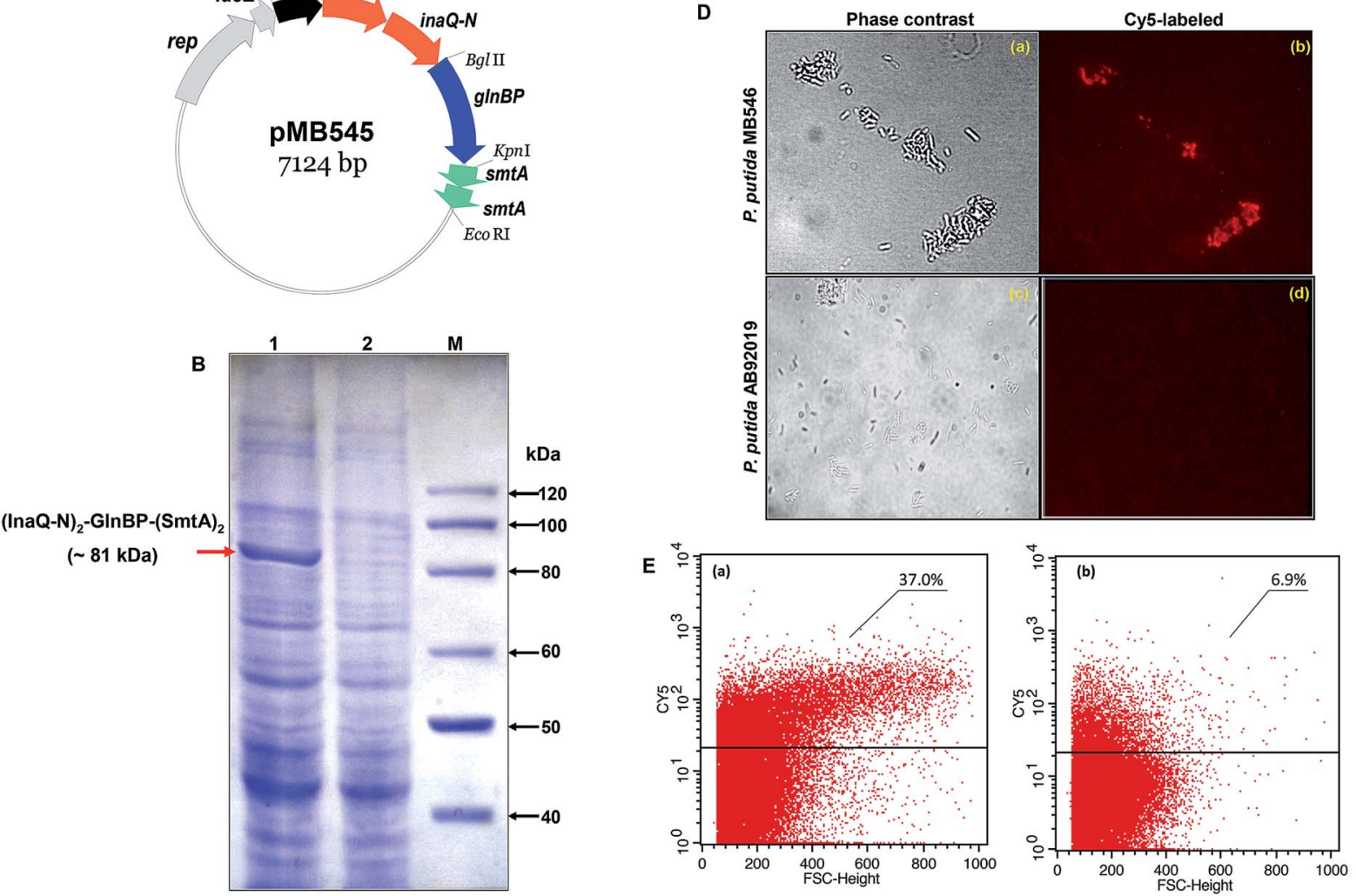

Fig. 1 Gene organization of the recombinant pMB545 plasmid (A) and surface localization assays of the fusion protein in $P$. putida MB546 cells. (A) ina $Q-N, N$-terminal domain of ice-nucleating protein gene ina $Q ;$ gln $B P$, glutamine-binding protein gene from $B$. thuringiensis $B M B 171$; smt $A$, cyanobacterial metallothionein protein gene; $P_{\text {opr }}$, constitutive promoter in $P$. putida; rep, plasmid replicon; lac $Z$, $\beta$-galactosidase gene. (B) SDSPAGE analysis of recombinant $P$. putida MB546 cells expressing the (InaQ-N) $)_{2}-\mathrm{GlnBP}-(\mathrm{SmtA})_{2}$ fusion protein. Lane 1 , $P$. putida MB546 cells; lane 2, P. putida AB92019 cells (negative control); lane M, protein Mr marker. (C) Western blot analysis of the P. putida MB546 cell fractions. WC, whole cell fraction; CP, cytoplasmic fraction; OM, outer membrane fraction; CK, P. putida AB92019 WC. (D) Immunofluorescence microscopic examination of Cy5-labeled P. putida MB546 and P. putida AB92019 (negative control) cells. (E) Flow cytometric analysis of Cy5-labeled MB546 cells. (a) P. putida MB546 cells; (b) P. putida AB92019 cells (negative control).

As shown in Fig. S1(a), $\uparrow \gamma$-PGA and EDC formed an unstable reactive $O$-acylisourea ester by NHS treatment; then, EDC was replaced with NHS to form a semi-stable amine-reactive NHS ester with $\gamma$-PGA, allowing the complete activation of $\gamma$-PGA ${ }^{24}$ and leading to the formation of stable amide bonds with the amino groups on the cell surface. As a result, the activated $\gamma$ PGA was bound to the bacterial surface. (ii) $\gamma$-PGA and GlnBP bind through ionic and hydrogen bonds. As shown in Fig. S1(b), $\dagger \gamma$-PGA can insert into the cavity between the two domains of GlnBP and can then become stabilized by forming ionic interactions and hydrogen bonds with glutamine and other aa residues around the cavity. ${ }^{17}$

The morphology of the MB546-PGA biocomposite that was or was not bound to the activated $\gamma$-PGA was examined using SEM. Both P. putida AB92019 cells (Fig. 2A) and AB92019 + PGA (Fig. 2B) were observed in natural dispersion states, without significant morphological differences. MB546 cells that were bound to the inactivated $\gamma$-PGA also appeared in a naturally dispersed state (Fig. 2C). However, the biocomposite MB546PGA formed a certain amount of cell aggregates (Fig. 2D). These results indicated that the formation of "Cell- $\gamma$-PGA-Cell surface SmtA" aggregates in the biocomposite MB546-PG and $\gamma$-PGA served as the crucial coupler to mediate cellular aggregation.

\section{$\mathrm{Cu}^{2+}$ adsorption of MB546-PGA}

Fig. $\mathrm{S} 2 \mathrm{~A} \uparrow$ showed that at $\mathrm{pH} 5.5,30{ }^{\circ} \mathrm{C}$, an initial $\mathrm{Cu}^{2+}$ concentration of $32 \mathrm{mg} \mathrm{L}^{-1}$ and a MB546-PGA loading equivalent to $0.6 \mathrm{mg} \mathrm{mL}^{-1}$ dry biomass, the $\mathrm{Cu}^{2+}$ adsorption reaction reached the equilibrium state in $15 \mathrm{~min}$, and $\mathrm{Cu}^{2+}$ removal efficiency reached $90 \%$ of the maximum value in $5 \mathrm{~min}$, reflecting the fast 

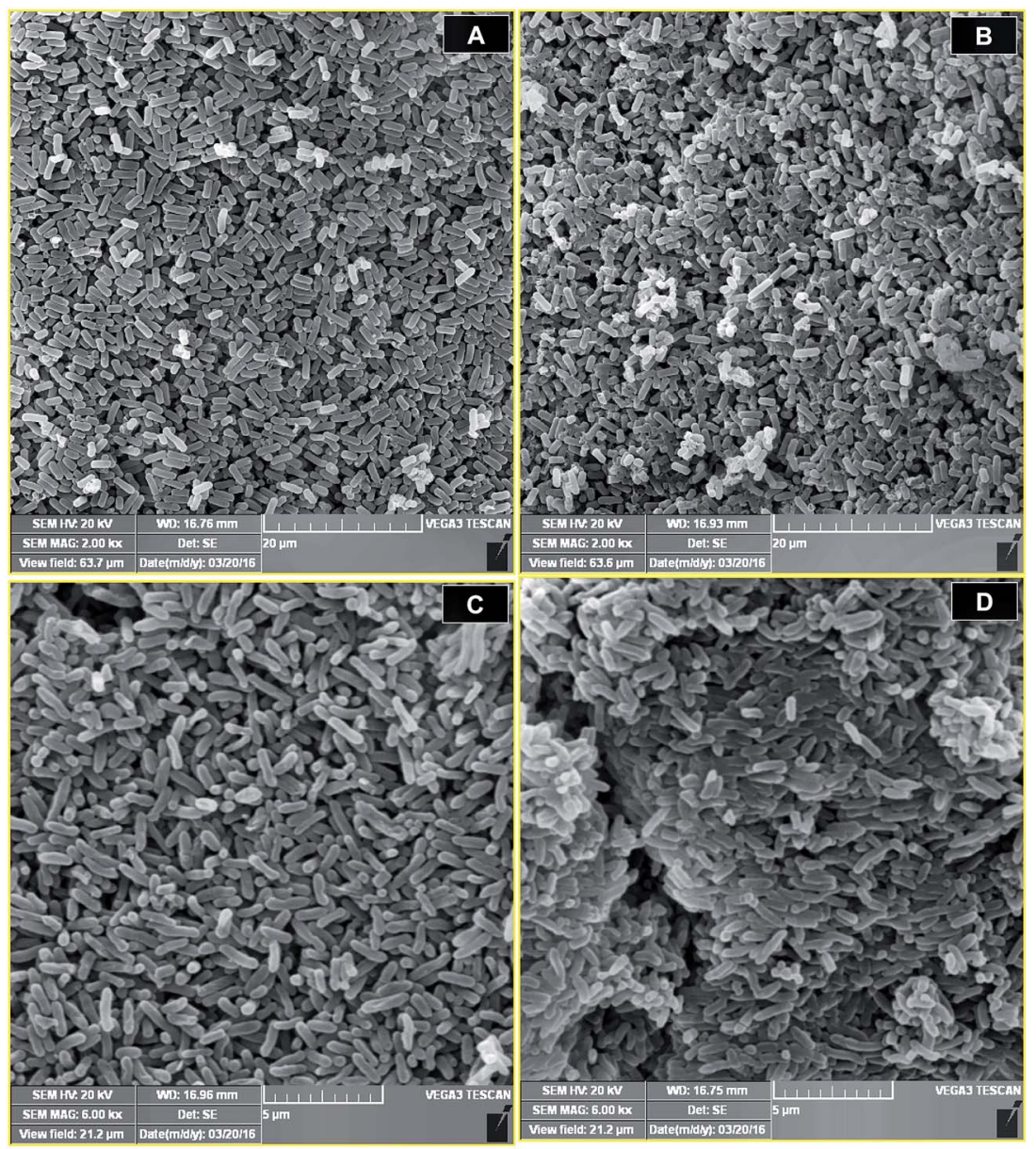

Fig. 2 Representative SEM micrograph of P. putida AB92019 cells (A), P. putida AB92019 cells+PGA (B), P. putida MB546 cells (C), and the MB546-PGA biocomposite (D).

adsorption reaction conducted by MB546-PGA. Fig. S2B and $\mathrm{S} 2 \mathrm{C} \dagger$ showed that the high $\mathrm{Cu}^{2+}$ removal efficiencies $(>96 \%)$ were maintained within a range of $20-60{ }^{\circ} \mathrm{C}$ and $\mathrm{pH} 3.5-5.5$, respectively. Fig. S2D $\uparrow$ shows that $\mathrm{Cu}^{2+}$ removal efficiencies were relatively stable at high levels (>96\%) across an MB546PGA loading range of $0.06 \mathrm{mg} \mathrm{mL}^{-1}$ to $1.8 \mathrm{mg} \mathrm{mL}^{-1}$.

Based on the results describe above, an optimized immobilization condition for $\mathrm{Cu}^{2+}$ biosorption by MB546-PGA can be defined as follows: a pH of $5.5,30{ }^{\circ} \mathrm{C}$, an initial $\mathrm{Cu}^{2+}$ concentration of $32 \mathrm{mg} \mathrm{L}^{-1}$, an adsorption time of $30 \mathrm{~min}$, and an MB546-PGA loading amount equivalent to $0.6 \mathrm{mg} \mathrm{mL} \mathrm{mL}^{-1}$ dry MB546 cells. Fig. 3 shows that these two materials exhibited consistent adsorption patterns for $\mathrm{Cu}^{2+}$ over the time course under the optimized adsorption conditions. The $\mathrm{Cu}^{2+}$ removal efficiency of MB546-PGA was higher than that of MB546 alone, with an ultimate increase in $\mathrm{Cu}^{2+}$ removal efficiency by approximately $13 \%$ in $30 \mathrm{~min}$. Two-way ANOVA analysis was performed at 0.05 significance level to evaluate whether the difference of $\mathrm{Cu}^{2+}$ removal efficiency between MB546 and MB546-PGA was significant or not. The ANOVA result (Table S1†) showed that the $P$ values of the factor A (MB546) and factor B (MB546-PGA) were all less than 0.01, indicating that the $\mathrm{Cu}^{2+}$ removal efficiency of MB546 and MB546-PGA is very significant.

\section{Kinetics of biosorption}

The optimum biosorption conditions were further applied to determine the $\mathrm{Cu}^{2+}$ adsorption capacity of MB546-PGA towards different initial $\mathrm{Cu}^{2+}$ concentrations of $6.4 \mathrm{mg} \mathrm{L}^{-1}, 12.8 \mathrm{mg} \mathrm{L}^{-1}$, $32.0 \mathrm{mg} \mathrm{L}^{-1}, 64.0 \mathrm{mg} \mathrm{L}^{-1}$, and $128.0 \mathrm{mg} \mathrm{L}^{-1}$. Fig. 4 shows that the biosorption of $\mathrm{Cu}^{2+}$ was rapid, with an approximately maximum adsorption equilibrium capacity obtained within the first 5 min towards low initial concentration of $\mathrm{Cu}^{2+}(6.4-32 \mathrm{mg}$ $\mathrm{L}^{-1}$ ), or approximately $90 \%$ of the maximum adsorption capacity towards a high initial concentration of $\mathrm{Cu}^{2+}(64-$ $128 \mathrm{mg} \mathrm{L}^{-1}$ ). The adsorption capacity maintained a stable or slightly increasing trend until the final adsorption equilibrium was obtained at $30 \mathrm{~min}$. Pseudo first-order and second-order equations were used to model the sorption data over the time course. The pseudo-first-order equation based on the adsorption equilibrium is represented as follows: $:^{25}$

$$
\ln \left(q_{\mathrm{e}}-q_{t}\right)=\ln q_{\mathrm{e}}-k_{1} t
$$

where $q_{\mathrm{e}}\left(\mathrm{mg} \mathrm{g}^{-1}\right)$ and $q_{t}\left(\mathrm{mg} \mathrm{g}^{-1}\right)$ are the amount of adsorbed $\mathrm{Cu}^{2+}$ per unit weight of MB546-PGA at equilibrium and time $t$, respectively; $k_{1}\left(\mathrm{~min}^{-1}\right)$ is a constant of the pseudo-first-order equation. 


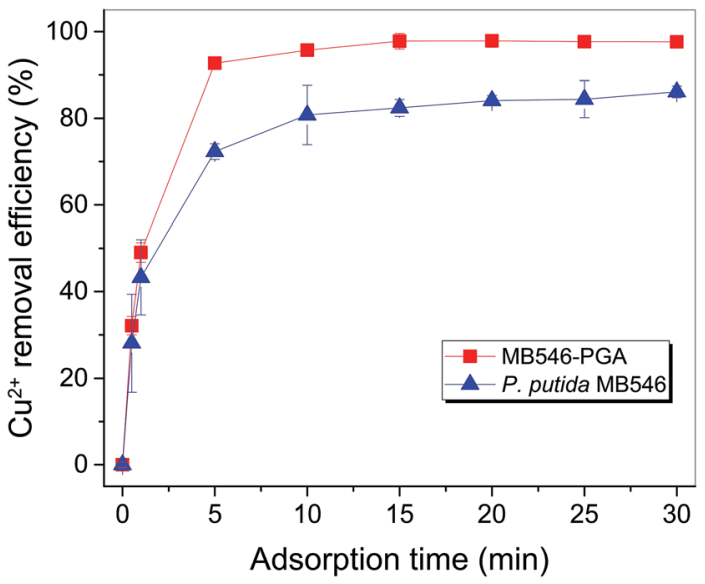

Fig. 3 Time course of $\mathrm{Cu}^{2+}$ removal efficiency by the MB546-PGA biocomposite and recombinant $P$. putida MB546 cells. All the biosorption experiments were performed in triplicate. Error bar showed the standard error for the experimental result.

The pseudo-second-order equation can be generally presented as follows: ${ }^{25}$

$$
\frac{t}{q_{t}}=\frac{1}{k_{2} q_{\mathrm{e}}^{2}}+\frac{t}{q_{\mathrm{e}}}
$$

where $q_{\mathrm{e}}\left(\mathrm{mg} \mathrm{g}^{-1}\right) q_{t}\left(\mathrm{mg} \mathrm{g}^{-1}\right)$ are the adsorbed $\mathrm{Cu}^{2+}$ amount at equilibrium and time $t$, respectively, and $k_{2}\left(\mathrm{~g} \mathrm{mg}^{-1} \mathrm{~min}^{-1}\right)$ is a constant of the pseudo-second-order equation.

The values of $\ln \left(q_{\mathrm{e}}-q_{t}\right)$ and $\frac{t}{q_{t}}$ were calculated. Since $\ln \left(q_{\mathrm{e}}-\right.$ $q_{t}$ ) and $t$ in eqn (1), and $\frac{t}{q_{t}}$ and $t$ in eqn (2) are linearly related, the time course sorption profiles were linearly fitted using eqn (1) and (2), and the data are shown in Fig. S3A and S3B. $\uparrow$ The fitting parameters of the pseudo-first-order kinetics and pseudo-second-order kinetics were shown in Tables S2 and S3. $\dagger$ Each value of Prob $>F$ of these two models was less than 0.01, indicating that both models were well fitted. Comparison of $R^{2}$ of each models indicated pseudo-second-order kinetics model $\left(R^{2}=0.98-0.99\right)$ was able to describe the sorption kinetics better. The pseudo-second-order equation show that as the initial $\mathrm{Cu}^{2+}$ concentration increased, the adsorption capacity $q_{\mathrm{e}}$ increased, and the pseudo-second-order kinetic constant $k_{2}$ was generally decreased.

\section{Biosorption isotherms}

The Langmuir model (Fig. S3C $\dagger$ ) and the Freundlich model (Fig. S3D $\dagger$ ) were used to analyze the biosorption isotherm data for $\mathrm{Cu}^{2+}$ adsorption by MB546-PGA at different initial $\mathrm{Cu}^{2+}$ concentrations. The Langmuir model assumes a monolayer sorption of a solute from a liquid solution and can be expressed as:

$$
\frac{1}{Q_{\mathrm{e}}}=\frac{1}{Q_{\max }}+\frac{1}{K_{\mathrm{s}} Q_{\max } C_{\mathrm{e}}}
$$

where $Q_{\mathrm{e}}\left(\mathrm{mg} \mathrm{g}^{-1}\right)$ is the adsorption capacity during equilibrium, $Q_{\max }\left(\mathrm{mg} \mathrm{g}^{-1}\right)$ is the maximum adsorption capacity of the material, $C_{\mathrm{e}}\left(\mathrm{mg} \mathrm{L}^{-1}\right)$ is the $\mathrm{Cu}^{2+}$ concentration in the liquid phase equilibrium, and $K_{\mathrm{s}}\left(\mathrm{mg} \mathrm{\textrm {L } ^ { - 1 }}\right)$ is the saturation constant.

The Freundlich model is based upon sorption on a heterogeneous surface, which can be expressed as:

$$
\ln Q_{\mathrm{e}}=\ln K_{\mathrm{f}}+1 / n\left(\ln C_{\mathrm{e}}\right)
$$

where $Q_{\mathrm{e}}$ and $C_{\mathrm{e}}$ are the same parameters indicated above, and $K_{\mathrm{f}}$ and $n$ are the Freundlich constants denoting the adsorption capacity and adsorption intensity, respectively.

The values of $Q_{\mathrm{e}}{ }^{-1}, C_{\mathrm{e}}{ }^{-1}, \ln Q_{\mathrm{e}}$ and $\ln C_{\mathrm{e}}$ were calculated. $Q_{\mathrm{e}}{ }^{-1}$ and $C_{\mathrm{e}}{ }^{-1}$ in eqn (3), and $\ln Q_{\mathrm{e}}$ and $\ln C_{\mathrm{e}}$ in eqn (4) are linearly related, and linear fitting of these parameters was adopted using the software Origin Pro 8 SRO v8.0724 (B724). The fitting parameters of the Freundlich isotherm and Langmuir isotherm models were calculated by fitting these equations. The results (Tables S4 and S5†) showed that the adsorption activity of MB546-PGA was more consistent with the Freundlich model $\left(R^{2}>0.99 ; P\right.$-value $\left.=6.85 \times 10^{-5}\right)$. Under optimized conditions, the MB546-PGA biosorbent obtained a maximum $\mathrm{Cu}^{2+}$ adsorption capacity of $145.99 \mathrm{mg} \mathrm{g}^{-1}$ through the Langmuir model and other isotherm model calculations.

\section{Flocculation induction by MB546-PGA}

Effective flocculation can definitely confer a desirable potential for the recovery of adsorbed heavy metal ions and for the enhanced overall removal capacity of metal ions. As shown in Fig. 5A and B, the combination of $0.04 \mathrm{M} \mathrm{CaCl}_{2}$ and $1 \mathrm{~g} \mathrm{~L}^{-1} \gamma$ PGA to MB546-PGA suspension or adding $0.04 \mathrm{M} \mathrm{CaCl}_{2}$ alone induced flocculation; however, $\gamma$-PGA alone failed to induce flocculation (Fig. 5C), indicating that $0.04 \mathrm{M} \mathrm{CaCl}_{2}$ induced flocculation. Interestingly, neither the $\mathrm{CaCl}_{2} / \gamma$-PGA combination nor $\mathrm{CaCl}_{2}$ or $\gamma$-PGA alone was able to induce flocculation in the control MB546 cell suspensions (Fig. 5E and F), suggesting that the distinctive "Cell- $\gamma$-PGA-Cell" linkages of MB546-PGA caused the formation of aggregates and that $\gamma$-PGA pivotally bound to cells and contributed to the flocculation upon $\mathrm{CaCl}_{2}$ induction.

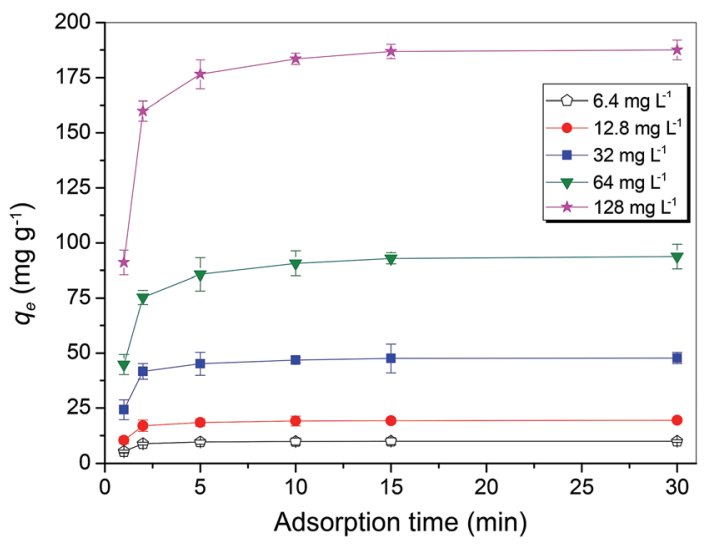

Fig. 4 Biosorption equilibrium curves for the MB546-PGA biocomposite at different $\mathrm{Cu}^{2+}$ ion concentrations. All the biosorption experiments were performed in triplicate. Error bar showed the standard error for the experimental result. 


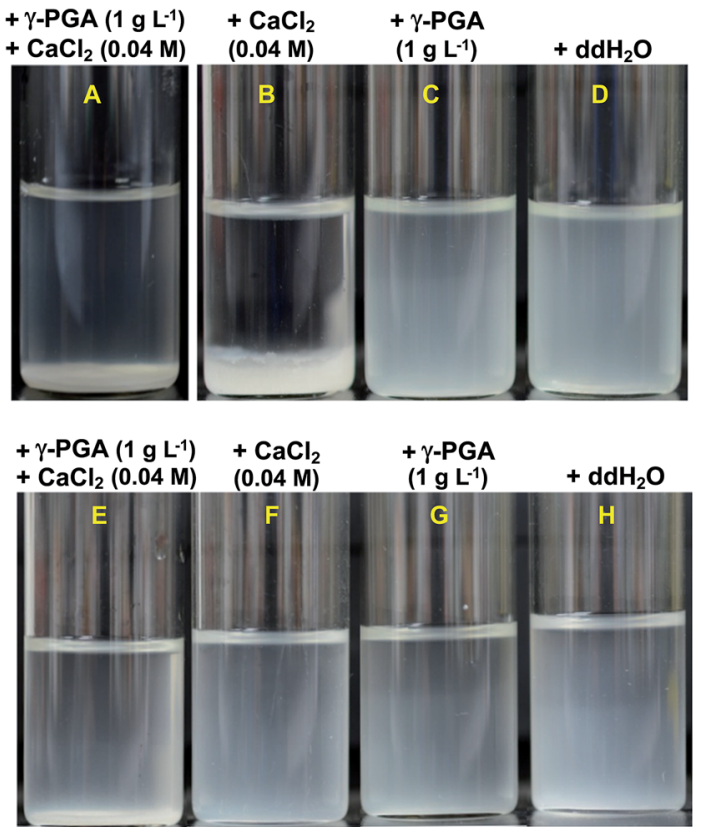

Fig. 5 Flocculation induced by the biocomposite MB546-PGA and $P$. putida AB92019 cells upon the addition of different inducers. (A), MB546-PGA; (B-D), P. putida MB546 cells; (E-H), P. putida AB92019 cells (negative control).

\section{The $\mathrm{Cu}^{2+}$ adsorption/desorption cycles}

Fig. S4 $\uparrow$ shows that in the first round, MB546-PGA exhibited $\mathrm{a} \mathrm{Cu}^{2+}$ adsorption capacity of $100 \mathrm{mg} \mathrm{g}^{-1}$ and an approximately half dissociation of $\mathrm{Cu}^{2+}$ at $\mathrm{pH}$ 2.5. However, in the second round, the $\mathrm{Cu}^{2+}$ adsorption of MB546-PGA significantly decreased to approximately $20 \%$ of the capacity in the first round, indicating that the low $\mathrm{pH}$ condition caused the remarkable ineffectiveness of this biomaterial for $\mathrm{Cu}^{2+}$ adsorption.

\section{FTIR spectroscopic analysis}

FTIR spectroscopic analyses of P. putida MB546 cells and MB546-PGA before and after $\mathrm{Cu}^{2+}$ adsorption were performed to verify the chemical groups that were involved in $\mathrm{Cu}^{2+}$ and $\gamma$-PGA binding. As shown in Fig. 6, the peaks in the 3300-2800 region were attributed to the vibrations of alkyl groups, such as $\mathrm{CH}_{3}$, $\mathrm{CH}_{2}$, and CH. ${ }^{10,26}$ The peaks at 1656.40 and $1651.39 \mathrm{~cm}^{-1}$ were produced by the stretching vibration of carbonyl groups in MB546 and MB546-PGA, respectively, in the absence of $\mathrm{Cu}^{2+}$ binding. The peaks at 1652.67 and $1650.73 \mathrm{~cm}^{-1}$ represent the stretching vibration of carbonyl groups in $\mathrm{Cu}^{2+}$-bound MB546 and $\mathrm{Cu}^{2+}$-bound MB546-PGA, respectively. The peaks at 1537.70 and $1541.90 \mathrm{~cm}^{-1}$ were attributed to the stretching vibration of the NH groups in MB546-PGA and unbound MB546, respectively, whereas the peaks at 1536.75 and $1540.41 \mathrm{~cm}^{-1}$ were attributed to the stretching vibration of the $\mathrm{NH}$ groups in $\mathrm{Cu}^{2+}$ bound MB546 and $\mathrm{Cu}^{2+}$-bound MB546-PGA, respectively. In addition, the peaks at 3385.85 and $3400.49 \mathrm{~cm}^{-1}$ were attributed to the stretching vibration of the hydroxyl groups in MB546-PGA prior to $\mathrm{Cu}^{2+}$ adsorption. These results showed that the vibrational peaks of the carbonyl and amino groups were shifted to low frequencies after $\gamma$-PGA bound to the MB546 cells, which suggested that the carbonyl and amino groups on the surface of the recombinant P. putida MB546 cells might be involved in the binding of $\gamma$-PGA to the cells. After $\mathrm{Cu}^{2+}$ was adsorbed by MB546-PGA, the vibrational peaks of the amino and hydroxyl groups were shifted to high frequencies, which indicated that the amino and hydroxyl groups of MB546-PGA might be involved in $\mathrm{Cu}^{2+}$ adsorption.

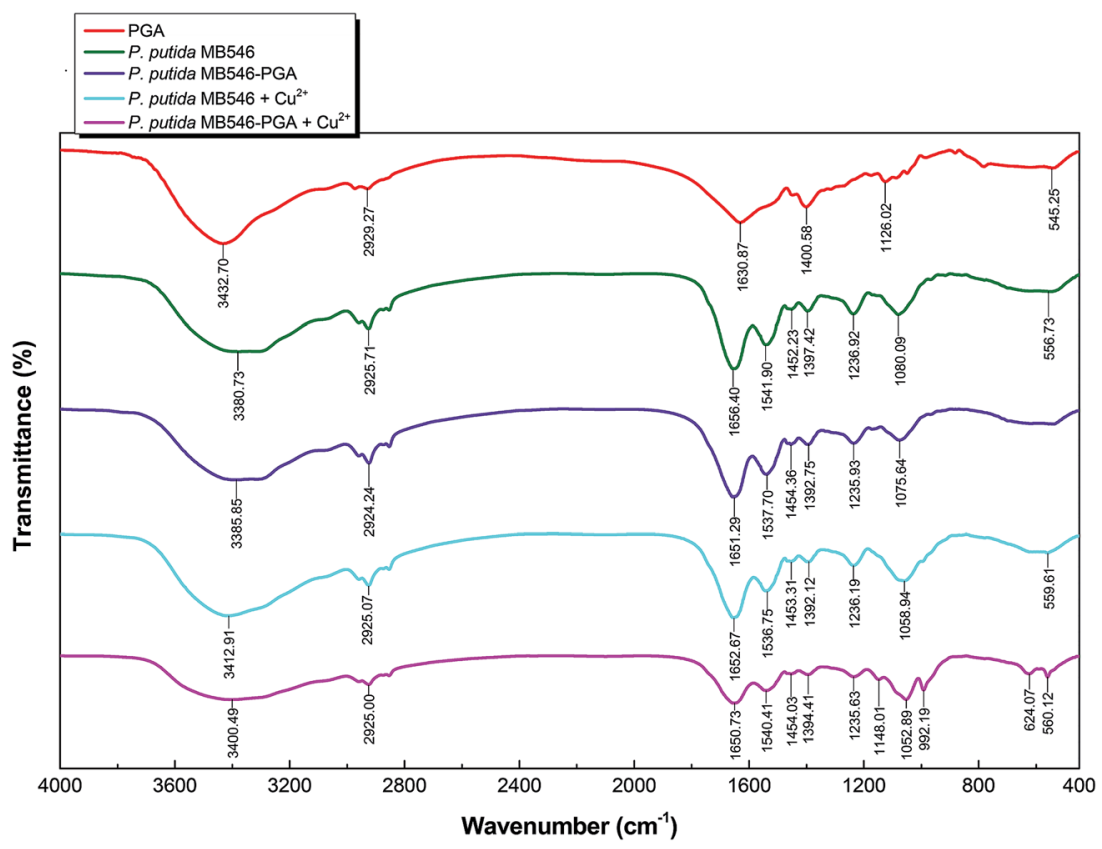

Fig. 6 FTIR spectra for MB546-PGA and P. putida MB546 cells before and after $\mathrm{Cu}^{2+}$ adsorption. 
The aim of this study was to construct a composite biosorbent with high adsorption and inducible flocculation capacities for the biosorption of $\mathrm{Cu}^{2+}$. The engineered P. putida cells that displayed SmtA and $\gamma$-PGA on their surface appear to be particularly valuable for this purpose because of their high $\mathrm{Cu}^{2+}$-binding activities and, for $\gamma$-PGA, the distinctive cellcoupling and inducible flocculation capabilities. The introduction of the glutamine-binding protein GlnBP to the fusion protein that was anchored on cell surface could be considered pivotal for the functionality of this system. Theoretically, $\gamma$-PGA could covalently bind to GlnBP by its Gln that acts as a ligand through an "enzyme-substrate" interaction mode. Previous investigations have revealed a cavity between the two domains of the GlnBP 3D structure that is presumed to bind Gln in $E$. coli. ${ }^{27}$ However, because GlnBP is trapped in the middle of the "triple" configuration of the fusion protein, it remains uncertain whether this structural configuration would affect the spatial structure of GlnBP and ultimately affect the formation of its cavity. Thus, we employed a type of EDC/NHS activation linkage method for $\gamma$-PGA to ensure that $\gamma$-PGA could effectively bind to GlnBP. The side chain carboxyl groups of $\gamma$-PGA were activated by EDC to form an unstable reactive $o$-acylisourea ester, which would react with NHS to form a semi-stable aminereactive NHS ester. The latter would react with the amino groups of various amino acids, such as lysine of GlnBP anchored on the cell surface, to form stable amide bonds, which ultimately allowed $\gamma$-PGA to bind to GlnBP. SEM observations, FTIR characterization, and the successful flocculation performance indicated that $\gamma$-PGA successfully bound to GlnBP. It is worth noting that $\gamma$-PGA itself serves a good adsorbent for heavy metals. ${ }^{28,29}$ Therefore, $\gamma$-PGA is definitely multifunctional in MB546-PGA in terms of cell coupling, flocculation initiation, and enhanced metal ion adsorption.

A bacterial adsorbent with an easy flocculation operation not only facilitates the recovery of metals but also extends the scope of potential applications, such as applications in still polluted or waste waters. Currently, the flocculation of MB546-PGA following $\mathrm{Cu}^{2+}$ adsorption was successfully conducted by adding the environmentally compatible and economically available $\mathrm{CaCl}_{2}$ in laboratory trials; however, the feasibility of this system must be validated in the naturally occurring real polluted water bodies where various metals and pollutants coexist and could cause interference in this system. The development of a system based on MB546-PGA that could be applied to real metalpolluted waters will be our next primary research goal.

\section{Conclusions}

This study reports a new biocomposite adsorbent that is capable of adsorbing $\mathrm{Cu}^{2+}$ at a high capacity and that induced flocculation following $\mathrm{Cu}^{2+}$ adsorption in aqueous solutions. Using cell surface display technology, a recombinant $P$. putida stain was constructed that enabled the expression of the fusion protein with two tandemly repeated InaQ-N anchors, the glutamine-binding protein GlnBP and two cyanobacterial metallothionein SmtA repeats on the cell surface. Through $\gamma$-PGAmediated covalent linkages, a triple biocomposite MB546-PGA consisting of "Cell- $\gamma$-PGA-Cell surface SmtA" was formed. The $\mathrm{Cu}^{2+}$ adsorption activity could be performed over a $\mathrm{pH}$ range of $3.5-5.5$ and a relatively broad temperature range of $20-60{ }^{\circ} \mathrm{C}$, and the activity rapidly reached equilibrium within $30 \mathrm{~min}$. The maximum adsorption capacity for $\mathrm{Cu}^{2+}$ reached $145.99 \mathrm{mg} \mathrm{g}^{-1}$. This biocomposite exhibited easy and efficient flocculation induced by $\mathrm{CaCl}_{2}$. Infrared analysis indicated that the hydroxyl and amino groups of MB546-PGA were involved in the adsorption of $\mathrm{Cu}^{2+}$, whereas the carbonyl and amino groups of $\gamma$-PGA were bound to $P$. putida cells and were involved in $\mathrm{Cu}^{2+}$ uptake.

\section{Experimental section}

\section{Chemicals, bacterial strains, plasmids, and culture conditions}

Industrial-grade $\gamma$-PGA ( $\mathrm{Na}^{+}$type) was purchased from SaiTaisi Biotechnology Co., Ltd. (Nanjing, China) and was used to construct the composite adsorbent. According to the manufacturer's quality inspection report, this $\gamma$-PGA product was a water-soluble homo-polypeptide polymerized by amide bonds on the $\gamma$-positions of mixed L-glutamic acid and D-glutamic acid monomers, with a polymerization degree ranging between $1000-15000$, a $\mathrm{Mr}$ of $\geq 1000 \mathrm{kDa}, \mathrm{pH} 5.0-7.0$, and a total purity of $\quad \geq 92 \%$. N-Hydroxysuccinimide (NHS) and 1-(3dimethylaminopropyl)-3-ethylcarbodiimide (EDC) were purchased from Adamas Reagent, Ltd. (Shanghai, China); 2-( $N$ morpholino) ethanesulfonic acid (MES) was purchased from Hefei New Source Biological Technology Co., Ltd. (Hefei, China). The wild-type P. putida Migula CCTCC (China Center for Type Culture Collection) AB92012 was used as the host strain for the construction of the surface display system. E. coli DH5 $\alpha$ (TaKaRa Bio Inc.) was used as a host strain for constructing the recombinant plasmids. The genome of Bacillus thuringiensis BMB171 (ref. 30) (Microbial Genetic Stock Center, Wuhan, China) was the source of the $\operatorname{gln} B P$ gene that encodes the glutamine-binding protein.

All plasmids used in this study are shown in Table S6. $\dagger$ All strains were routinely cultured in lysogeny broth (LB) medium according to standard cultivation procedures. ${ }^{31}$ Recombinant $E$. coli cells were grown at $37{ }^{\circ} \mathrm{C}$ in LB broth containing $100 \mu \mathrm{g}$ $\mathrm{mL}^{-1}$ (final concentration) ampicillin (Amp), whereas recombinant $P$. putida cells were grown at $28{ }^{\circ} \mathrm{C}$ in LB broth containing $500 \mu \mathrm{g} \mathrm{mL} \mathrm{m}^{-1}$ (final concentration) carbenicillin (Cb).

\section{Construction of the recombinant plasmids}

All polymerase chain reaction (PCR) primers used to construct the various recombinant plasmids are listed in Table S6. $\dagger$ Total bacterial and plasmid DNA were prepared according to standard methods. ${ }^{32}$ The construction of all recombinant plasmids is schematically illustrated in Fig. S5. $\dagger$ Briefly, an 846-bp $g \ln B P$ gene was amplified by PCR from the $B$. thuringiensis BMB171 genome with the primers glnBP-F (BglII site underlined) and glnBP1-R (EcoRI site underlined). The amplified fragment was digested with BglII and EcoRI, followed by ligation into the BglII/ EcoRI site of a previously digested pMB109 plasmid, yielding the recombinant pMB541 plasmid harboring the fusion gene (inaQ$\mathrm{N}_{2}-\mathrm{g} \ln \mathrm{BP}$. Using inaQ-N-F (NcoI site underlined) and glnBP2-R 
(PstI site underlined) as the primers, an 1894-bp fusion gene $(\text { inaQ }-N)_{2}-g \ln B P$ fragment was amplified by PCR from the pMB541 plasmid. The resulting fragment was digested with NcoI and PstI and was inserted into NcoI/PstI sites of the pTrcHis B E. coli expression vector to yield the 6185-bp recombinant pMB542 plasmid. PCR amplification was performed using primers smtA-F (KpnI site underlined) and smtA-R (EcoRI site underlined) to obtain two tandemly aligned smtA repeats from the pYN2S plasmid. After digesting this fragment with KpnI/ EcoRI, it was ligated into the KpnI/EcoRI site of pMB542 to yield a 6525-bp recombinant pMB544 plasmid. Finally, pMB544 was digested with $N c o I / E c o R I$, and the 2252 bp digested fragment was inserted into the NcoI/EcoRI sites of the Pseudomonas expression vector pYNP to yield a 7124-bp recombinant plasmid pMB545, which harbored the fusion gene (inaQ-N) $)_{2}-g \ln B P-$ $(s m t A)_{2}$.

E. coli were transformed using standard protocols. ${ }^{31}$ Recombinant $E$. coli strains harboring the recombinant pMB541, pMB542, pMB544, and pMB545 plasmids were named E. coli MB541, MB542, MB544, and MB545, respectively. $P$. putida AB92019 were transformed by electroporation using a previously described protocol. ${ }^{33}$ Recombinant $P$. putida AB92019 harboring the recombinant plasmid pMB545 was designated as P. putida MB546.

\section{Cell fractionation and preparation of cell surface proteins}

P. putida MB546 cells were grown at $28{ }^{\circ} \mathrm{C}$ for $24 \mathrm{~h}$ and the cells were collected to prepare the fractionated samples following a previously described method. ${ }^{34}$ Equal volumes of each fractionated sample were subjected to SDS-PAGE and Western blot assays.

\section{SDS-PAGE and Western blot analyses}

P. putida MB546 cells and fractionated samples, as described above, were subjected to SDS-PAGE analysis on a $10 \%$ separation gel using a previously described method. ${ }^{35}$ For the fractionated samples, Western blot analyses were further performed to verify the expression of the (InaQ-N) $)_{2}-\mathrm{GlnBP}-$ (SmtA $)_{2}$ fusion protein using polyclonal InaQ-N antiserum as the primary antibody and horseradish peroxidase-conjugated goat anti-mice IgG (Chemicon, USA) as the secondary antibody, according to previously described procedures. ${ }^{36}$

\section{Immunofluorescence microscopy and FACS analysis}

Immunofluorescence microscopy and FACS analysis of the recombinant $P$. putida MB546 cells were performed according to a previously described method, ${ }^{37}$ except that the polyclonal InaQ-N antiserum was used as the primary antibody. FACS measurements were recorded as the percentage of total fluorescence-labeled cells relative to the total Cy5 fluorescence.

\section{SEM}

Morphological observations of $P$. putida MB546 cells and the biocomposite adsorbent MB546-PGA were conducted using a JSM-6390/LV SEM (NTC, Japan). The sample preparation procedures, including glutaraldehyde fixing, ethanol dehydration, freeze drying, and gold-plating the specimens, were performed according to the manufacturer's instructions.

\section{Construction of MB546-PGA by conjugating MB546 and $\gamma$-PGA}

The biocomposite MB546-PGA was conjugated with the activated carboxyl side chains of $\gamma$-PGA and the surface-active groups of MB546 cells. A single LB-plate colony of a P. putida MB546 culture was incubated in LB broth and grown at $28{ }^{\circ} \mathrm{C}$ with shaking at $150 \mathrm{rpm}$ for $12 \mathrm{~h}$. The inoculum $(1 \%, \mathrm{v} / \mathrm{v})$ was inoculated into a $500 \mathrm{~mL}$ Erlenmeyer flask loaded with $200 \mathrm{~mL}$ of LB broth, and the culture was grown at $28{ }^{\circ} \mathrm{C}$ with shaking at $200 \mathrm{rpm}$ for $24 \mathrm{~h}$. The cells were collected by centrifugation

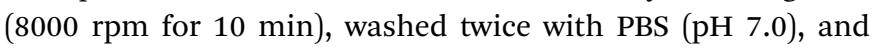
resuspended to an $\mathrm{OD}_{600}$ of 1.5 with $\mathrm{ddH}_{2} \mathrm{O}$, which was subsequently used for conjugation with $\gamma$-PGA. Each $50.0 \mathrm{~mL}$ aliquot of the resuspended cells was desiccated at $180{ }^{\circ} \mathrm{C}$ for $2 \mathrm{~h}$ to weigh the net biomass.

The conjugation of MB546 cells and $\gamma$-PGA was performed using the following procedures. Firstly, an appropriate amount of $\gamma$-PGA was dissolved in the activation buffer (0.1 M MES and $0.5 \mathrm{M} \mathrm{NaCl}, \mathrm{pH}$ 6.0) to a final concentration of $1 \mathrm{mg} \mathrm{mL}^{-1}$ (i.e., Solution I), and $0.4 \mathrm{mg}$ of EDC (final concentration of $2 \mathrm{mM}$ ) and $0.6 \mathrm{mg}$ of NHS (final concentration $5 \mathrm{mM}$ ) that had previously been equilibrated to room temperature (RT) were sequentially added to Solution I. The mixed solution was incubated at RT with shaking at $60 \mathrm{rpm}$ for $15 \mathrm{~min}$, and $1.4 \mu \mathrm{L}$ of $\beta$ mercaptoethanol (final concentration of $20 \mathrm{mM}$ ) were added to stop the reaction to yield activated Solution I. Secondly, an appropriate amount of the resuspended $P$. putida MB546 cells, which was equivalent to $6 \mathrm{mg} \mathrm{mL}^{-1}$ dry weight, was added to the coupling buffer (100 mM phosphate and $150 \mathrm{mM} \mathrm{NaCl}, \mathrm{pH} 7.2$ ) to yield Solution II. Finally, equal volumes of activated Solution I and Solution II were mixed, incubated at RT with shaking at $60 \mathrm{rpm}$ for $2 \mathrm{~h}$, and centrifuged at $8000 \mathrm{rpm}$ for $1 \mathrm{~min}$ to obtain the biocomposite MB546-PGA. This biomaterial was washed three times with $\mathrm{ddH}_{2} \mathrm{O}$, then diluted to a unit concentration equivalent to $6 \mathrm{mg} \mathrm{mL}^{-1}$ dry weight of MB546 cells with $\mathrm{ddH}_{2} \mathrm{O}$, and stored at $4{ }^{\circ} \mathrm{C}$ until use. For use as the control, $P$. putida AB92019 cells were treated in parallel to prepare the composite material named AB92019 + PGA.

\section{Biosorption experiments}

Unless otherwise specified, the $\mathrm{Cu}^{2+}$ adsorption through MB546-PGA was conducted at an initial $\mathrm{Cu}^{2+}$ concentration of $32 \mathrm{mg} \mathrm{L^{-1 }}$ in a shaker-flask at $60 \mathrm{rpm}$. The experiments were conducted by varying the adsorption time (0-30 $\mathrm{min})$, temperature $\left(20-60{ }^{\circ} \mathrm{C}\right), \mathrm{pH}(3.5-5.5)$, and MB546-PGA loading amount (equivalent to $0.06-1.8 \mathrm{mg} \mathrm{mL}{ }^{-1}$ dry weight of MB546 cells) to investigate the optimal biosorption conditions. After the biosorption reaction, the supernatants were collected via centrifugation at $12000 \mathrm{rpm}$ for $30 \mathrm{~s}$. The residual $\mathrm{Cu}^{2+}$ contents of the supernatants were determined using an atomic absorption spectrophotometer (HITACHI 180-80, Japan). The residual $\mathrm{Cu}^{2+}$ contents were used to calculate the absolute $\mathrm{Cu}^{2+}$ removal efficiency using the following equation: 


$$
\mathrm{Cu}^{2+} \text { removal efficiency }(\%)=\frac{\left(C_{\mathrm{i}}-C_{\mathrm{e}}\right)}{C_{\mathrm{i}}} \times 100 \%
$$

where $C_{\mathrm{i}}$ denotes the initial $\mathrm{Cu}^{2+}$ content $\left(\mathrm{mg} \mathrm{L}^{-1}\right)$, and $C_{\mathrm{e}}$ denotes the equilibrium $\mathrm{Cu}^{2+}$ content $\left(\mathrm{mg} \mathrm{L}^{-1}\right)$ post-adsorption.

\section{Kinetics and isotherm analysis}

The biosorption experiments were performed with different initial $\mathrm{Cu}^{2+}$ concentrations ranging from $6.4 \mathrm{mg} \mathrm{L}^{-1}$ to $128.0 \mathrm{mg}$ $\mathrm{L}^{-1}$ under the optimized reaction conditions (i.e., pH 5.5, $30^{\circ} \mathrm{C}$ and $30 \mathrm{~min})$. After the biosorption reaction equilibrium was reached, the residual $\mathrm{Cu}^{2+}$ content in the corresponding supernatant from each initial $\mathrm{Cu}^{2+}$ concentration was measured using the method described above. The equilibrium of the $\mathrm{Cu}^{2+}$ adsorption capacity $\left(q_{\mathrm{e}}, \mathrm{mg} \mathrm{g}^{-1}\right)$ was plotted, and the adsorption isotherm curves were established. Adsorption capacity was calculated using the following equation:

$$
q_{\mathrm{e}}=\frac{\left(C_{\mathrm{i}}-C_{\mathrm{e}}\right)}{M}
$$

where $C_{\mathrm{i}}$ denotes the initial Cu(II) ion concentration $\left(\mathrm{mg} \mathrm{g}^{-1}\right), C_{\mathrm{e}}$ denotes the equilibrium $\mathrm{Cu}(\mathrm{II})$ concentration $\left(\mathrm{mg} \mathrm{L}^{-1}\right)$, and $M$ denotes the biomass amount of the MB546-PGA biocomposites and MB546 cells. The biosorption experiments were performed in triplicate. Kinetics and isotherm data was linearly fitted using the software OriginPro 8 SRO v8.0724 (B724).

\section{Desorption experiments}

$\mathrm{A} \mathrm{Cu}^{2+}$ solution with an initial concentration of $64 \mathrm{mg} \mathrm{L}^{-1}$ was used for the adsorption/desorption experiments with MB546PGA at an equivalent loading dry weight of $0.6 \mathrm{mg} \mathrm{mL}^{-1}$. The adsorption experiments were conducted under the reaction conditions of $\mathrm{pH} 5.5$ and $30{ }^{\circ} \mathrm{C}$ and were agitated at $60 \mathrm{rpm}$ for $30 \mathrm{~min}$. The biosorbents were harvested, washed three times with sterile $\mathrm{dd}_{2} \mathrm{O}$, and resuspended in a pH 2.5 solution. After shaking at $60 \mathrm{rpm}$ for $30 \mathrm{~min}$, the biosorbents were harvested and washed with a large amount of sterile deionized water before being used for a second round of adsorption/desorption experiments. The residual or redissolved $\mathrm{Cu}^{2+}$ contents in the corresponding solutions were measured using the method described above. The desorption experiments were performed in triplicate, and the adsorption capacity was calculated according to eqn (6), whereas the $\mathrm{Cu}^{2+}$ desorption capacity $\left(q_{\mathrm{d}}, \mathrm{mg} \mathrm{g}^{-1}\right)$ was calculated using the following equation:

$$
q_{\mathrm{d}}=\frac{C_{\mathrm{d}} \times V}{M}
$$

where $C_{\mathrm{d}}$ denotes the equilibrium $\mathrm{Cu}(\mathrm{II})$ concentration $\left(\mathrm{mg} \mathrm{L}^{-1}\right)$ post-desorption, $V$ denotes the volume of the desorption reaction solution, and $M$ denotes the mass concentration of MB546PGA.

\section{Flocculation experiments}

The flocculation activity of MB546-PGA induced by $\mathrm{dd}_{2} \mathrm{O}, \gamma$ PGA and $\mathrm{CaCl}_{2}$ was recorded by measuring the $\mathrm{OD}_{600}$ of supernatant following the flocculation reaction. Each $20 \mathrm{~mL}$ MB546-PGA suspension (with a biomass concentration equivalent to $0.6 \mathrm{mg} \mathrm{mL}^{-1}$ dry weight of MB546 cells) was mixed with $\mathrm{ddH}_{2} \mathrm{O}, 1 \mathrm{~g} \mathrm{~L}^{-1}$ (final concentration) of $\gamma$-PGA, $0.04 \mathrm{M}$ (final concentration) $\mathrm{CaCl}_{2}$, or a combination of $\gamma$-PGA and $\mathrm{CaCl}_{2}$. After stirring briefly, the mixed solutions were placed at RT for $30 \mathrm{~min}$ to monitor the occurrence of flocculation. For the control experiments, the flocculation induced by the unconjugated P. putida MB546 and P. putida AB92019 cells was examined in parallel.

\section{FTIR}

The infrared spectra of MB546-PGA before and after $\mathrm{Cu}^{2+}$ adsorption, as well as the free or $\gamma$-PGA-bound P. putida MB546 cells, were analyzed using an FTIR spectrometer (Spectrum One, Perkin-Elmer) within the 400 to $4000 \mathrm{~cm}^{-1}$ range. The samples were generally prepared using previously described procedures. ${ }^{26}$

\section{Data analysis}

All data were averaged from triplicate assays. The statistical analyses were performed using SPSS 17.0 statistical software. Statistical significance was defined as a $P$-value less than 0.05 .

\section{Acknowledgements}

This work was supported by grants from the National Natural Science Foundation of China (Grant No. 31270158 and 31570123), the National Key Research and Development Program of China (Program No. 2016YFD0800702), and the Fundamental Research Funds for the Central Universities (Grant number 2662015PY189).

\section{Notes and references}

1 M. Bilal, J. A. Shah, T. Ashfaq, S. M. Gardazi, A. A. Tahir, A. Pervez, H. Haroon and Q. Mahmood, J. Hazard. Mater., 2013, 263, 322-333.

2 J. Y. Tseng, C. Y. Chang, C. F. Chang, Y. H. Chen, C. C. Chang, D. R. Ji, C. Y. Chiu and P. C. Chiang, J. Hazard. Mater., 2009, 171, 370-377.

3 B. Dhir, Environ. Sci. Pollut. Res., 2014, 21, 1614-1627.

4 J. Wang and C. Chen, Biotechnol. Adv., 2009, 27, 195-226.

5 R. Gupta and H. Mohapatra, Indian J. Exp. Biol., 2003, 41, 945-966.

6 Y. A. Yahaya, M. Mat Don and S. Bhatia, J. Hazard. Mater., 2009, 161, 189-195.

7 J. Wang and C. Chen, Bioresour. Technol., 2014, 160, 129-141. 8 S. M. Lee, Lalhmunsiama, S. I. Choi and D. Tiwari, Environ. Sci. Pollut. Res., 2013, 20, 7464-7477.

9 K. Tsekova, D. Todorova, V. Dencheva and S. Ganeva, Bioresour. Technol., 2010, 101, 1727-1731.

10 H. Ni, Z. Xiong, T. Ye, Z. Zhang, X. Ma and L. Li, Chem. Eng. J., 2012, 204-206, 264-271.

11 J. M. Buescher and A. Margaritis, Crit. Rev. Biotechnol., 2007, 27, 1-19.

12 A. Ogunleye, A. Bhat, V. U. Irorere, D. Hill, C. Williams and I. Radecka, Microbiology, 2015, 161, 1-17. 
13 Z. Luo, Y. Guo, J. Liu, H. Qiu, M. Zhao, W. Zou and S. Li, Biotechnol. Biofuels, 2016, 9, 134.

14 B. Manocha and A. Margaritis, Crit. Rev. Biotechnol., 2008, 28, 83-99.

15 I. B. Bajaj and R. S. Singhal, Food Bioprocess Technol., 2009, 4, 745-752.

16 S. W. Chang, J. F. Shaw, K. H. Yang, S. F. Chang and C. J. Shieh, Bioresour. Technol., 2008, 99, 2800-2805.

17 Y. J. Sun, J. Rose, B. C. Wang and C. D. Hsiao, J. Mol. Biol., 1998, 278, 219-229.

18 F. A. Quiocho, Philos. Trans. R. Soc., B, 1990, 326, 341-351.

19 K. Kuroda and M. Ueda, Curr. Opin. Biotechnol., 2011, 22, 427-433.

20 M. Vasak and D. W. Hasler, Curr. Opin. Chem. Biol., 2000, 4, 177-183.

21 J. Shi, W. P. Lindsay, J. W. Huckle, A. P. Morby and N. J. Robinson, FEBS Lett., 1992, 303, 159-163.

22 Q. Li, Q. Yan, J. Chen, Y. He, J. Wang, H. Zhang, Z. Yu and L. Li, Int. J. Biol. Sci., 2012, 8, 1097-1108.

23 T. Ye, C. Yao, Q. Li, H. Zhang and L. Li, Chin. J. Appl. Environ. Biol., 2008, 14, 528-533.

24 Z. Grabarek and J. Gergely, Anal. Biochem., 1990, 185, 131135.

25 M. Iqbal, A. Saeed and S. I. Zafar, J. Hazard. Mater., 2007, 148, 47-55.

26 K. Akhtar, A. M. Khalid, M. W. Akhtar and M. A. Ghauri, Bioresour. Technol., 2009, 100, 4551-4558.
27 C. D. Hsiao, Y. J. Sun, J. Rose and B. C. Wang, J. Mol. Biol., 1996, 262, 225-242.

28 B. S. Inbaraj, C. P. Chiu, G. H. Ho, J. Yang and B. H. Chen, J. Hazard. Mater., 2006, 137, 226-234.

29 J. Yao, H. Xu, J. Wang, M. Jiang and P. Ouyang, J. Biomater. Sci., Polym. Ed., 2007, 18, 193-204.

30 J. He, X. Shao, H. Zheng, M. Li, J. Wang, Q. Zhang, L. Li, Z. Liu, M. Sun, S. Wang and Z. Yu, J. Bacteriol., 2010, 192, 4074-4075.

31 J. Sambrook and D. W. Russell, Molecular cloning: a laboratory manual, Cold Spring Harbor Laboratory Press, Cold Spring Harbor, N.Y., New York, 3rd edn, 2001.

32 F. M. Ausubel, R. Brent, R. E. Kingston, D. D. Moore, J. G. Seidman, J. A. Smith and K. Struhl, Current protocols in molecular biology, John Wiley \& Sons, Inc., New York, 5 th edn, 2002.

33 K. Iwasaki, H. Uchiyama, O. Yagi, T. Kurabayashi, K. Ishizuka and Y. Takamura, Biosci., Biotechnol., Biochem., 1994, 58, 851-854.

34 L. Li, D. G. Kang and H. J. Cha, Biotechnol. Bioeng., 2004, 85, 214-221.

35 U. K. Laemmli, Nature, 1970, 227, 680-685.

36 Q. Li, H. Ni, S. Meng, Y. He, Z. Yu and L. Li, J. Microbiol. Biotechnol., 2011, 21, 1330-1335.

37 Q. Li, Z. Yu, X. Shao, J. He and L. Li, FEMS Microbiol. Lett., 2009, 299, 44-52. 